\title{
Consumption of Contaminated Eggs: A Public Health Concern
}

\author{
Saif N. Al-Bahry ${ }^{1}$, Ibrahim Y. Mahmoud ${ }^{2}$, Salma K. Al-Musharafi ${ }^{3}$, and James R. Paulson ${ }^{4} *$
}

\author{
${ }^{1}$ Department of Biology \\ College of Science \\ Sultan Qaboos University \\ Muscat, Sultanate of Oman \\ snbahry@squ.edu.om \\ ${ }^{2}$ Department of Biological \\ Sciences and Chemistry \\ University of Nizwa \\ Nizwa, Sultanate of Oman \\ ibrahim.younis@unizwa.edu.o \\ $\underline{\mathrm{m}}$

${ }^{3}$ Department of Applied
Biotechnology
Sur College of Applied
Sciences
Sur, Sultanate of Oman
salma.sur@cas.edu.om \\ ${ }^{4}$ Department of Chemistry \\ University of Wisconsin- \\ Oshkosh \\ Oshkosh, WI 54901 USA \\ paulson@uwosh.edu
}

*Author for correspondence:

$+1-920-424-7100$

\begin{abstract}
The presence of pathogenic bacteria and fungi in food and the contamination of food with heavy metals and organic pollutants have become major global public health issues and economic concerns. Although eggs are often thought of as perfect, naturally packaged sources of nutrition, the eggs of chickens, other fowl, and sea turtles are in fact among the most commonly contaminated foods worldwide. The egg cuticle and eggshell are generally ineffective in preventing the entry of microbes and some chemicals. As a result of the overuse of antibiotics, pathogenic microorganisms that invade eggs are often found to be resistant to antimicrobial drugs. In addition, due to heavy usage in agriculture and various industries, synthetic organic chemicals and heavy metals enter the environment and can find their way into food chains and eventually contaminate eggs. In an effort to minimize these various types of contamination, regulations have been established to control the egg industry. However, in some regions of the world enforcement is lax and compliance is poor. The aim of this paper is to raise awareness of the need for rigorous enforcement of the rules, greater industry compliance with standards, increased monitoring, and further research on the public health issues.
\end{abstract}

Keywords: Eggs, contamination, microbes, organic pollutants, heavy metals. 


\section{Introduction}

Eggs are an important source of nutrition worldwide and are used in many food products. In the U.S., chicken eggs are touted as "the incredible edible egg", a neatly packaged and nutritious natural food [27]. The eggs of other fowl are also consumed throughout the world and in some regions sea turtle eggs are also an important food.

In recent years, however, contamination of food has become a serious global concern, and this problem also affects eggs. In fact, among food products, eggs from poultry and sea turtles are some of the most common sources of bacterial and fungal pathogens as well as chemical contaminants such as synthetic organic compounds and heavy metals. These pathogens and chemical contaminants may be acquired from the environment as a result of the pollution of soil and water, but they may also be present in the ingredients used in the manufacture of animal feed [41]. Contamination of poultry products is reported to be the most common factor involved in health issues related to food consumption [117].

Pathogenic bacteria such as Salmonella are the cause of several major clinical syndromes, the most common of Copyright 2015 KEI Journals. All Rights Reserved which is gastroenteritis. This has become an international public health concern as well as an economic issue [66]. Typical symptoms are vomiting, chills, headaches, fever and abdominal cramping. Those most at risk are the elderly, young children, immunocompromised patients and pregnant women. Severe complications are possible which can lead to lengthy hospitalization if the bacterial infection invades organs outside the gastrointestinal tract [39].

Food safety procedures have been established as strategies to control such contamination, including separation of raw and finished food products, pest control, proper personnel training and monitoring [101]. Nevertheless, it is apparent that these measures have been insufficient to prevent egg contamination, since epidemiological investigations have traced numerous outbreaks to infected eggs [66].

In this paper, we first discuss the structure of eggs and the mechanisms by which pathogens penetrate eggs. This topic has been of great interest to microbiologists and to the poultry industry [48]. We then discuss antibiotic-resistant bacteria in relation to egg contamination, and touch on the problem of fungal contamination of eggs. Finally, we present information about chemical contamination of eggs with heavy $2 \mid \mathrm{P}$ a g e 
metals and persistent organic pollutants. Our goals are to highlight these problems and also to increase awareness of the need for more research, more effective regulations, and better industry compliance with the rules and standards that exist.

\section{Egg structure}

Eggs use several different physical and chemical defense mechanisms to prevent microbial infections, and the cuticle, the egg shell, and underlying membranes comprise the first line of defense. In fowl, the outer layer of the egg, on the outside of the shell, is usually the cuticle which consists of a waxy material made up of $90 \%$ protein, 3\% lipid, 4\% carbohydrate and 3\% ash [40]. This component serves to decrease the permeability of eggshell pores [114].

Immediately after oviposition the cuticle is ineffective in preventing the entry of microorganisms, but shortly thereafter it hardens. This hardening blocks infection by microbes and also makes the cuticle resistant to water penetration $[48,92]$. Even after this point, however, breaks in the cuticle occasionally occur, allowing microorganisms to invade the egg contents and cause infections.

Chicken eggshells consist predominantly of calcium carbonate crystals Copyright 2015 KEI Journals. All Rights Reserved
(95\% or more) which are stabilized by a matrix of proteins [28]. The calcified layer is called the palisade layer because it is laid down in the form of columns. Such structural characteristics provide higher strength and stronger resistance to fracture and to external contamination.

The strength of the eggshell is affected both by its ultrastructure and by its thickness, which varies among egg-laying animals. In chicken eggs, for example, the thicker the eggshell the stronger it will be structurally. The tightly fused palisade layer, with its narrow and combined interstitial spaces, makes the eggshell stronger [62]. Eggshell color, strength, weight and thickness are all related to the egg's quality. Lighter color indicates a tenderer eggshell with a higher number of eggshell pores [116].

The porous nature of the avian eggshell is essential for gas exchange by the embryo. The columns of the palisade layer form narrow pores which cross the eggshell and allow for the passage of $\mathrm{O}_{2}$ and $\mathrm{CO}_{2}$. The size and number of these submicroscale pores play an important role in the exchange of materials such as gases and other chemicals because they determine which molecules can traverse the eggshell and how efficiently they can do so [119]. 
Underlying the cuticle and the eggshell are the outer and inner eggshell membranes which are rich in keratin and lined by mucopolysaccharide [30, 105, 111]. The eggshell membrane consists of flexible fibers which partition the albumen and yolk $[34,86,104]$. The outer eggshell membrane contains thick fibers intermingled with narrow fibers, acting as a barrier and thus helping to prevent infection $[44,111,114]$.

The egg albumen mainly contains proteins such as lysozyme, avidin, and ovotransferrin [40]. These chemical components of the albumen provide a second line of defense against microbial infections. Lysozyme has lytic activity against Gram-negative bacterial lipid A of lipopolysaccharide (LPS) and hydrolyzes glycosidic bonds in microbial proteoglycans $[66,102]$. Ovotransferrin defends against bacterial infection by a different mechanism: it prevents bacterial growth by means of its iron chelating activity [40]. In addition to these components of the albumen, the egg yolk contains several classes of antibodies with bacteriostatic characteristics. The predominant immunoglobin in egg yolk is $\operatorname{IgG}$, but $\operatorname{IgM}$ and $\operatorname{IgA}$ are also present [33, 73-74].

Sea turtle eggs are used as a food source by some people living in coastal Copyright 2015 KEI Journals. All Rights Reserved regions of the world, including Oman, and detailed ultrastructural studies relating to their eggs have been reported. In particular, Al-Bahry et al. [5, 15] have studied the eggs of the green turtle, Chelonia mydas, and the loggerhead, Caretta caretta. The structure of sea turtle eggshells is somewhat different from that of birds. It is made up of three major layers: the outer calcareous, the middle multistrata, and the inner shell membrane. The calcareous layer consists of different sizes and shapes of nodular units that are loosely attached to each other, creating uneven spaces that allow for air, water and heat exchange. The multistrata layer is composed of numerous highly compacted strata with various shapes of crystals. It is made up of small units with irregular pores that connect the calcareous layer with the inner shell membrane. The inner shell membrane consists of a network of reticular fibers. In the eggs of the loggerhead, this network of reticular fibers is particularly extensive which makes the eggshell membrane sturdier.

\section{Mechanisms and Consequences of Bacterial infection}

Eggs can become infected with bacteria either by vertical transmission from the mother or by horizontal transmission

$$
4 \mid \mathrm{P} \text { a g e }
$$


from the surroundings. Vertical transmission takes place in the reproductive system, specifically in the ovaries and oviduct, when the eggshell has not yet formed and microbes are capable of penetrating the egg relatively easily. Horizontal transmission can take place during laying as a result of exposure to contaminated oviductal fluid or fecal material $[8,10,36]$. Alternatively, eggs can become infected via horizontal transmission after laying. In this case, the contamination is derived from feces or other sources in the environment [47, 114]. Contaminated fecal material plays a major role in horizontal infection when there are breaks in the eggshell [36]. Horizontal transmission may take place soon after laying, or later during collection, shipping and storage. If refrigeration is inadequate during shipping and storage, bacterial growth can lead to rapid deterioration of the egg contents.

Foodborne microbes can cause a variety of infections, and outbreaks resulting from egg contamination are on the rise, becoming public health concerns and leading to significant economic losses [76, 117]. Egg contamination with Salmonella was reported to be the most common infection in the United States and Europe during the last few years [65], followed by Copyright 2015 KEI Journals. All Rights Reserved
Staphylococcus aureus [117] and other Gram negative bacteria [36]. Chills, abdominal cramps, headache, fever, vomiting and diarrhea are common symptoms [39]. In some cases, microbial pathogens and spoilage-opportunistic microbes cause outbreaks of infection specifically in immunocompromised individuals.

Such food spoilage microbes respond to the egg's defenses in ways that allow them to survive in the harsh egg environment. Many pathogens adopt mechanisms that enable them to grow and reproduce inside the egg where they may secrete toxins that cause food poisoning [9].

For a successful infection, a microbial pathogen has to accomplish three things: adherence to the egg, penetration of the eggshell, and survival within the albumen and yolk. Achieving these three steps then enables the pathogen to grow and multiply in the interior of the egg. It is of great importance to understand these processes so that such infections can be prevented or minimized. Since many bacteria have developed mechanisms enabling them to survive and multiply within host cells and within eggs [112], it is best if they are never allowed to invade the host in the first place. 
Recent ultrastructural studies using scanning electron microscopy have revealed that microbes can penetrate through specific pores of eggshells to establish successful infection in the albumen and yolk [5, 9, 15, 18, 69, 87]. The eggshell pores are therefore considered a portal of entry for infectious bacteria [106].

Many investigators have used artificial infection of eggs in order to understand the processes by which bacteria penetrate the eggshell, albumen and yolk. Such experiments involve the application of a known inoculum of bacteria to the egg under carefully controlled conditions. Not surprisingly, the longer the egg is exposed to the spoilage microbes, the higher the rate of penetration $[9,46]$. In addition, a higher microbial concentration in the inoculum results in a higher rate of penetration [88]. Javed et al. [77] reported that $1 \times 10^{6}$ colony forming units per milliliter (cfu/mL) of Salmonella can penetrate egg components within 3-5 minutes, and Cason et al. [46] found that S. typhimurium can infect eggs in 6 minutes. Berrang et al. [36] reported that with $10^{4} \mathrm{cfu} / \mathrm{mL}$ of Salmonella, infection occurs within 30 minutes, whereas with a lower Salmonella concentration $\left(10^{3}\right.$ $\mathrm{cfu} / \mathrm{mL}$ ) penetration took 2 hours. This indicates clearly that inoculum size is an Copyright 2015 KEI Journals. All Rights Reserved important factor affecting the infection process in Salmonella spp. Similar findings have been reported by Catalano and Knabel [47] and Al-Bahry et al. [9].

Some investigators have reported different mechanisms of infection according to the microbial species. Penetration by motile bacteria is faster than by non-motile forms. The non-motile microbes are nevertheless able to diffuse through the eggshell in a moist environment [9, 69]. Among the motile Gram-negative bacteria, such as Pseudomonas, Escherichia, and Salmonella, different mechanisms of infection are used [9]. Some species, such as S. typhimurium, gain entry by becoming coccobacilli in shape $[9,18,92]$.

Al-Bahry et al. [9] compared the rates of eggshell penetration by Pseudomonas aeruginosa, S. typhimurium and E. coli and found that $P$. aeruginosa penetrated most readily. On the other hand, De Reu et al. [53] found that the rates of penetration of $P$. aeruginosa and S. enteritidis were similar. Al-Bahry et al. [9] also reported that $S$. typhimurium and Staphylococcus aureus that had invaded chicken eggs had a lower microbial population in the albumen compared to the yolk, probably due to antimicrobial substances in the albumen such as ovotransferrin and lysozyme [40].

$$
6 \mid \mathrm{P} \text { a g e }
$$


Similar results have been reported for $S$. typhimurium in turtle eggs [5]. However, $P$. aeruginosa and E. coli were able to resist the antimicrobial activities in the albumen [9]. Although yolk is rich in $\operatorname{IgM}, \operatorname{IgG}$ and IgA immunoglobulins, it is nevertheless considered to be an excellent nutrient medium for microbial growth [5, 9, 40, 92].

The infection mechanisms of these bacteria are also temperature dependent, with the optimum growth temperature for infection ranging between 35 and $37^{\circ} \mathrm{C}$ [9, 117]. The optimum conditions for infection would be an environment that is warm and moist. The presence of oxygen also enhances microbial penetration of eggs [80].

Infections can be minimized by taking appropriate precautions during collection, preservation and transportation of eggs. Proper environmental conditions in laying facilities should be maintained, with nest sanitation paramount [93], and facilities should be kept cool and dry [68]. Proper temperature procedures should be adhered to, along with the proper storage temperature in the retail markets.

Commercial procedures are now making wide use of pasteurization [67]. It should be noted that cooking methods are very important. Blankenship et al. [38] and Davidson and Witty [51] reported that Copyright 2015 KEI Journals. All Rights Reserved boiling an egg for $15 \mathrm{~min}$ is effective. However, it has been suggested that if massive levels of microbes are present no cooking method is safe [55]. In particular, frying, soft cooking and scrambling are not sufficient to kill all pathogens [31, 75]. It has also been reported that by means of altered gene regulation, some pathogens are able to adapt to low and high $\mathrm{pH}$ conditions, enabling them to survive in either acidic or alkaline environments.

\section{Antimicrobial drug resistance}

Microbial contamination of food is a serious concern, but the seriousness of the problem is compounded by the increasing prevalence of antibiotic drug resistant (ADR) microbes. Spreading of ADR microbes, specifically in food, is becoming a serious global concern that has a direct impact on human health. After a half century of antimicrobial drug usage, the World Health Organization (WHO) in 2014 reported for the first time a drastic global diminishment in the effectiveness of the antimicrobial drugs which control pathogens [115]. This report covers 114 countries, indicating that resistance to antimicrobial drugs is serious and widespread.

Although antibiotic-resistance can arise in the human microbiome as a result of 
clinical therapeutic use of these drugs, the digestive tracts of farm animals are an even more significant breeding ground for ADR microbes. This is due to the excessive prophylactic use of antibiotics as additives in animal feed, and the consequent natural selection of microbes that carry resistance determinants [17]. This of course ultimately makes the drugs inactive against pathogens and thus ineffective in the use for which they are intended. It is estimated that more than $80 \%$ of ADR microbes have emerged as a result of antibiotic usage in animal feed stocks [78].

Continuous usage of antimicrobial drugs in animal feed has improved animal health and led to better and more efficient egg and meat production. However, this practice has aggravated the emergence of ADR bacteria, which has led to increasing frequency of food infection outbreaks [35]. ADR microbes are now the major cause of outbreaks from contaminated food.

Since food animal operations on farms are a major source of ADR microbes, they clearly provide opportunities for these microbes to spread to chicken eggs. As discussed above, this can occur either by vertical transmission from an infected hen, or horizontally from fecal material. However, ADR microbes can also reach Copyright 2015 KEI Journals. All Rights Reserved eggs and other foods from the broader environment.

Antibiotic resistance has become nearly ubiquitous in the environment [17], and globally ADR microbes have been reported from a wide variety of different habitats $[26,43,45,82-83,90,98,110]$. ADR microbes can enter terrestrial and aquatic environments via runoff from feedlots or from fields where manure is spread as fertilizer, and via industrial and municipal waste streams. Sewage treatment plants are not able to eliminate these microbes and may even breed them when waste streams include effluent from hospitals and pharmaceutical industries [17]. Contaminated sewage effluents are probably one of the main sources of pollution in Oman. Pollution from these sources may affect underground water that is used in food production and consumption [16-17]. ADR microbes have been isolated from prepared food, chicken carcasses and intestines, well water, water distribution systems and soil [1-5, 12-13, 16-17]. Contaminated sewage effluents have been reported to transfer the $\mathrm{ADR}$ microbes to terrestrial and marine habitats, even after tertiary treatment of waste water. This has resulted in infections of fish and sea turtles. 
ADR bacteria have been isolated from fish, turtles and snails in Oman [5-6, 85].

ADR bacteria have been isolated from sea turtle eggs and oviductal fluids $[5,8,10$, 15, 17]. Many coastal communities with large sea turtle populations, in Oman for example, consume turtle eggs in their diet. When these eggs are infected, consumption can lead to serious illnesses [4, 6, 8].

\section{Mycoses}

Several different species of fungi have been isolated from sea turtle eggs, and the presence of these organisms is associated with reduced hatching success and the death of embryos [57, 60-61, 94]. Ultrastructural studies reveal that pathogenic fungi invade egg contents by means of hyphae [60-61, 107-108], and the fungi use the internal egg contents as a source of nutrients [60-61].

Investigators have found that fungi isolated from unhatched eggs, embryos and sand samples are all similar [60-61, 84, 89, 94-95, 97, 107-108]. Pathogenic fungi that have been isolated from sea turtle eggs include Aspergillus and Fusarium species, and many of the species that have been found are mycotoxigenic. These include $F$. moniliforme, A. ochraceus, A. flavus, and Penicillium spp. [57, 60-61, 84, 89, 95-96, 107]. In some cases mutagenic mycotoxins such as aflatoxin are produced by these Copyright 2015 KEI Journals. All Rights Reserved organisms [79, 91]. For example, A. flavus isolated from eggshells of green turtles (Chelonia mydas), was found to secrete aflatoxin at concentrations between 0.3 and $28 \mathrm{ppb}$ when grown in liquid medium [61]. Fungal growth in eggshells can also inhibit gas exchange and deplete the calcium content of the eggshell, affecting embryonic development [107].

\section{Heavy Metals and Persistent Organic Pollutants}

In addition to contamination by microbes, eggs can become contaminated with chemical pollutants that are acquired from the environment or from animal feed. The chemicals of concern can be either inorganic heavy metals or organic compounds. As with microbial contamination, sewage that is released to the environment is often the ultimate source of these pollutants. However, they may also be derived from agricultural operations, industrial activity, mining, or natural processes such as forest fires and volcanism. For example, Yildiz and Yener [118] reported heavy metal contamination that came from soil contaminated with volcanic material.

Heavy metal pollution has been reported in both terrestrial and marine 
habitats [15, 20-25, 103], and even treated sewage can be a source of this contamination. Studies have revealed that heavy metals are not entirely removed during sewage water treatment $[5-6,11,15$, 20-24]. Treated industrial sewage effluent and sludge contain various heavy metals depending on the source of the effluent [1516, 20-24, 71, 103].

If such effluents are used in the production of poultry feed, heavy metals may ultimately be incorporated into eggs. Contamination of chicken feed and other animal feed with heavy metals has been reported, and metals such as $\mathrm{Cd}, \mathrm{Cu}, \mathrm{Mn}, \mathrm{Ni}$ and $\mathrm{Zn}$ have been detected in egg components $[32,52,99]$.This can affect egg quality and may lead to undesirable consequences when the eggs are consumed.

Eggs become contaminated with heavy metals during eggshell formation [42, 58]. Appropriate levels of some minerals and metals are important for optimum production of eggs, and some metals, such as $\mathrm{Fe}, \mathrm{Cu}, \mathrm{Co}, \mathrm{Mn}$ and $\mathrm{Zn}$, are essential trace elements for growth of both microbes and higher organisms [7]. However, at higher concentrations these trace elements become toxic due to their ability to bind to biological molecules, leading to enzyme inactivity, neurotoxicity, and induction of mutations Copyright 2015 KEI Journals. All Rights Reserved and cancers in humans and other animals [72]. Some heavy metals, such as $\mathrm{Pb}$, are highly toxic even at low levels $[52,118]$.

Environmental pollution appears to be the source of heavy metal contamination in sea turtle eggs. Heavy metals have been detected in green turtle eggs using X-ray microanalysis with scanning electron microscopy, and study of the yolk of green turtles eggs from Ras Al-Hadd, Oman, has revealed that nest sand was the source of the $\mathrm{Cr}, \mathrm{Co}, \mathrm{Cu}, \mathrm{Pb}, \mathrm{Hg}, \mathrm{Ni}$ and $\mathrm{Se}$ found in those eggs [15, 25].

Fish feeding near the dumping site of treated sewage water have been found to contain heavy metals, providing clear evidence that treated waste streams can be a source of contamination [22]. It is likely that sea turtle feeding habitats and nesting areas are also being polluted by industrial effluents contaminated with heavy metals [19]. Some of the heavy metals detected in eggshells, such as $\mathrm{Y}, \mathrm{Yb}$ and Te, are rare in nature but are heavily used in industry [19, 56]. Thus, heavy metals in biological samples are an indication of environmental contamination from industrial waste $[15,19$ $24,81]$.

Persistent organic pollutants (POP) are chemicals that remain undegraded in the environment for long periods of time and 
have undesirable effects on wildlife and on human health. POP bioaccumulate in the food chain and may become toxic when consumed by organisms at the top of the food chain. There are two types of POP: naturally occurring substances that arise from wildfires and volcanic activity, and synthetic, man-made chemicals such as pesticides, pharmaceuticals and solvents. The two categories differ in the severity of the diseases that they cause [100].

Dioxins, DDT (1,1,1-trichloro-2,2di(4-chlorophenyl)ethane), polychlorinated biphenyls (PCBs) and chlorinated pesticides are the most common POP. These compounds have been found in egg contents from small private farms as well as from large commercial farms; in fact, Van Overmeire et al. [113] reported greater contamination in eggs from private farms than from commercial farms. The soil is the source of these contaminants. Some of these compounds, such as DDT, can cause thinning of the eggshell [109]. Dioxin has been found in eggs by some European investigators [29, 59, 63-64, 70].

In Oman, samples from poultry farms have been found to be contaminated with antimicrobial drugs [3, 9, 12-14]. Although strict regulations have been introduced, they are not sufficiently enforced, and the use of antibiotics in animals is still widespread. In some countries, regulations concerning antimicrobial drug use on farms still need to be implemented. According to Donoghue [54], American farmers are generally in compliance with Food and Drug Administration (FDA) and US Department of Agriculture (USDA) regulations on the use of antimicrobial drugs. However, many consumers continue to worry about the drug and hormone content of foods, including poultry products. Presence of antimicrobial drugs in foods can cause several health problems including general toxicity, hypersensitivity reactions, teratogenicity and carcinogenicity. In addition, tetracycline deposition in bones can cause inhibition of bone growth [49]. Tetracycline, macrolides, $\beta$-lactams, sulfonamides, lincosamides and quinolone have all been detected in egg contents [37]. Other investigators have reported that the contents of most foods, including eggs, exceeded World Health Organization (WHO) maximum residue levels and that tetracycline was the most commonly detected drug [50]. Similar cases have been reported in Oman [12, 14].

\section{Conclusions:}

$11 \mid \mathrm{P}$ a g e 
In summary, eggs are one of the most common foods and are used in many food products, but egg quality is significantly affected by microbial and chemical contaminants. Bacterial contamination is very common in eggs and consumption of contaminated eggs may lead to serious infections. Many chemicals, including heavy metals, pesticides, antibiotics and other drugs, may also contaminate eggs during their development. Such contaminants are extremely dangerous and can lead to serious health problems.

Although regulations to control the egg industry have been adopted in many countries to prevent these types of contamination, they are not necessarily adequate and the industry does not always comply. In order to reduce the various types of contamination and minimize the adverse effects on human health, more rigorous enforcement of and adherence to the established rules and standards will be essential. In addition, further research on methods and approaches to prevent and deal with egg contamination is badly needed, and should contribute significantly to improved public health.

\section{Acknowledgements:}

Copyright 2015 KEI Journals. All Rights Reserved
We are grateful to Mr. T. Grogan for assistance in facilitating the preparation of this manuscript.

\section{References}

[1] Al-Bahry SN. "Antibiotic resistance of Salmonella isolated from Muscat, Oman," Pakistan Journal of Biological Sciences, vol. 2, no. 2 (1999): 523-528, url: http://198.170.104.138/pjbs/1999/523528.pdf.

[2] Al-Bahry SN. "Plasmid profiles of antibiotic resistant Salmonella species isolated in Muscat, Oman," Pakistan Journal of Biological Sciences, vol. 3, no. 2 (2000): 215-218, url: http://docsdrive.com/pdfs/ansinet/pjbs/2000/ 215-218.pdf.

[3] Al-Bahry SN, Al-Mashani BM, Elshafie AE, Pathare N, Al-Harthy AH. "Plasmid profile of antibiotic resistant Escherichia coli isolated from chicken intestines," Journal of Alabama Academy of Sciences vol. 77, no. 3-4 (2006): 152-159.

[4] Al-Bahry SN, Elshafie AE, Al-Busaidi S, Al-Hinai JA, Al-Shidi, I. "Antibiotic resistant Salmonella spp. from human and non-human sources in Oman," Eastern Mediterranean Health Journal, vol. 13, no. 1 (2007): 49-55, url: http://apps.who.int/iris/bitstream/10665/117 223/1/13_1_2007_49_55.pdf?ua=1

[5] Al-Bahry SN, Mahmoud IY, Elshafie AE, Al-Harthy A, Al-Ghafri S, Al-Amri I, Alkindi AY. "Bacterial flora and antibiotic resistance from eggs of green turtles Chelonia mydas: an indication of polluted effluents," Marine Pollution Bulletin, vol. 12 | P a g e 
58, no. 5 (2009): 720-725, url: http://www.seaturtle.org/PDF/AlBahryS_2009_MarPollutBull.pdf

[6] Al-Bahry SN, Mahmoud IY, AlBelushi KI, Elshafie AE, Al-Harthy A, Bakheit CK. "Coastal sewage discharge and its impact on fish with reference to antibiotic resistant enteric bacteria and enteric pathogens as bio-indicators of pollution," Chemosphere, vol. 77, no. 11 (2009): 15341539. url: hohenheim.de/fileadmin/einrichtungen/hebr ew-university/Literature/AlBahry-etalChemos2009.pdf

[7] Al-Bahry SN, Mahmoud IY, Al-Khaifi A, Elshafie AE, Al-Harthy, A. "Viability of multiple antibiotic resistant bacteria in distribution lines of treated sewage effluent used for irrigation," Water Science \& Technology, vol. 60, no. 11 (2009): 29392948.

[8] Al-Bahry SN, Mahmoud IY, Al-Zadjali M, Elshafie A, Al-Harthy A, Al-Alawi W. "Antibiotic resistant bacteria as bio-indicator of polluted effluent in the green turtles, Chelonia mydas in Oman," Marine Environmental Research, vol. 71, no. 2 (2011): 139-144.

[9] Al-Bahry SN, Mahmoud IY, AlMusharafi SK, Al-Ali MA. "Penetration of spoilage and food poisoning bacteria into fresh chicken egg: a public health concern," Global Journal of Bioscience and Biotechnology (GJBB), vol. 1, no. 1 (2012): 33-39.

[10] Al-Bahry SN, Al-Zadjali MA, Mahmoud IY, Elshafie AE. "Biomonitoring marine habitats in reference to antibiotic resistant bacteria and ampicillin resistance

Copyright 2015 KEI Journals. All Rights Reserved determinants from oviductal fluid of the nesting green sea turtle, Chelonia mydas," Chemosphere, vol. 87, no. 11 (2012): 13081315.

url: http://www.sciencedirect.com/science/article /pii/S0045653512001439

[11] Al-Bahry SN, Mahmoud IY, AlMusharafi SK. "Antibiotic resistant bacteria used as bioindicators of environmental pollution produced by tertiary treated sewage effluent," in Water Pollution XI, WIT Transactions on Ecology and the Environment vol. 164, C.A. Brebbia, Ed., WIT Press, Southampton, UK, 2012, pp. 313-321.

[12] Al-Bahry SN, Mahmoud IY, AlMusharafi SK. "The overuse of tetracycline compounds in chickens and its impact on human health," IPCBEE, vol. 50, no. 1 (2013): 21-25.

[13] Al-Bahry SN, Al-Hinai JA, Mahmoud IY, Al-Musharafi SK. "Opportunistic and microbial pathogens in municipal water distribution systems," APCBEES Procedia, vol. 5 (2013): 339-343. url: http://www.sciencedirect.com/science/article /pii/S2212670813000596

[14] Al-Bahry SN, Al-Mashani BM, AlAnsari AS, Elshafie AE, Mahmoud IY. "Escherichia coli tetracycline efflux determinants in relation to tetracycline residues in chicken," Asian Pacific Journal of Tropical Medicine, vol. 6, no. 9 (2013): 718-722.

url: http://www.sciencedirect.com/science/article /pii/S199576451360125X

[15] Al-Bahry SN, Mahmoud I, Al-Rawahi $\mathrm{S}$, Paulson JR. "Egg contamination as an indicator of environmental health," in Eggs: 
Nutrition, Consumption and Health. W. Segil and H. Zou, Eds., Nova Science Publishers, Inc. Hauppauge, New York, USA, 2013, pp. 1-24.

[16] Al-Bahry SN, Mahmoud IY, AlMusharafi SK, Al-Gharaibi IS, Al-Harthy NK, Al-Zadjali HA. "Microbial and chemical pollution of water-wells relative to sewage effluents in Oman," IAFOR Journal of Sustainability, Energy and the Environment (IJSEE), vol. 1, no. 1 (2014): 35-56. url: http://iafor.org/archives/journals/sustainjournal/IJSEEv1n1a4.pdf

[17] Al-Bahry SN, Mahmoud IY, Paulson JR, Al-Musharafi SK. "Antibiotic resistant bacteria in terrestrial and aquatic environments: a review," International Arabic Journal of Antimicrobial Agents, vol. 4, no. 3 (2015): 1-11. url: http://imed.pub/ojs/index.php/IAJAA/article /viewFile/985/665

[18] Al-Lawati IJ, Al-Bahry SN, Ba-Omar T, Elshafie AE. "The use of SEM in studying infected chicken eggs by Salmonella typhimurium," Microscopy and Microanalysis, vol. 9, suppl. 2 (2003): 14901491.

[19] Al-Musharafi SK. "Analysis of heavy metal in eggshells of green turtles, Chelonia mydas, by scanning electron microscopy and x-ray microanalysis," in Biotechnology and Conservation of Species from Arid Regions, S.A. Farooq, R.M.M. Abed and S. Baqir, Eds, Nova Science Publishers, Inc., Hauppauge, New York, USA, 2014, pp. 137-144.

[20] Al-Musharafi SK, Mahmoud IY, AlBahry SN. "Heavy metal contamination from treated sewage effluents," in Water

Copyright 2015 KEI Journals. All Rights Reserved
Pollution XI, WIT Transactions on Ecology and the Environment vol. 164, C.A. Brebbia, Ed., WIT Press, Southampton, UK, 2012, pp. 381-389.

[21] Al-Musharafi SK, Mahmoud IY, AlBahry SN. "Heavy metal pollution from treated sewage effluent," APCBEES Procedia, vol. 5 (2013): 344 - 348. url: http://www.sciencedirect.com/science/article /pii/S2212670813000602

[22] Al-Musharafi SK, Mahmoud IY, AlBahry SN. "Contamination of marine fish by heavy metals from coastal sewage treated effluent runoff," The Third Asian Conference on Sustainability, Energy and the Environment, acsee2013, The International Academic Forum (IAFOR), Osaka, Japan, 2013, pp. 100-107. url: https://www.researchgate.net/publication/25 1881085 Contamination of marine fish $b$ y_heavy_metals_from_coastal_sewage treat ed_effluent_runoff

[23] Al-Musharafi SK, Mahmoud IY, AlBahry SN. "Environmental contamination by industrial effluents and sludge relative to heavy metals," Journal of Geoscience and Environment Protection, vol. 2, no. 2 (2014): 14-18. url: http://dx.doi.org/10.4236/gep.2014.22003

[24] Al-Musharafi SK, Mahmoud IY, AlBahry SN., "Environmental hazards and pollution from liquid waste lagoons," IPCBEE, vol. 69, no. 1 (2014): 1-5.

[25] Al-Rawahy SH, Al Kindi AY, Elshafie A, Mahmoud IY, Al-Bahry SN, Al-Siyabi SS, Mansour MH, Al-Kiyumi AA. "Accumulation of metals in the egg yolk and liver of hatchling of green turtles Chelonia mydas at Ras Al Hadd, Sultanate of Oman," ANSI: Journal of Biological Sciences, vol. 7, 
no. 6 (2007): 925-930. url: http://www.docsdrive.com/pdfs/ansinet/jbs/2 007/925-930.pdf

[26] Allen HK, Donato J, Wang HH, Cloud-Hansen KA, Davies J, Handelsman J. "Call of the wild: antibiotic resistance genes in natural environments," Nature Reviews Microbiology, vol. 8, no. 4 (2010): 251-259. url:

http://www.nature.com/nrmicro/journal/v8/n 4/full/nrmicro2312.html

[27] American Egg Board, www.incredibleegg.org, 2015. Accessed 15 March 2015.

[28] Arias JL, Fernandez MS. "Role of extracellular matrix molecules in shell formation and structure," World's Poultry Science Journal, vol. 57, no. 3 (2001): 349357.

[29] Baars AJ, Bakker MI, Baumann RA, Boon PE, Freijer JI, Hoogenboom LA, Hoogerbrugge $\mathrm{R}$, van Klaveren JD, Liem AK, Traag WA, de Vries J. "Dioxins, dioxin-like PCBs and non-dioxin-like PCBs in foodstuffs: Occurrence and dietary intake in The Netherlands," Toxicology Letters, vol. 151, no. 1 (2004): 51-61. url: http://www.researchgate.net/publication/852 $\underline{8513}$

[30] Baker JR, Balch DA. "A study of the organic material of the hen's-egg shell," Biochemical Journal, vol. 82, no. 2 (1962): 352-361. url: http://www.ncbi.nlm.nih.gov/pmc/articles/P MC1243460/pdf/biochemj00806-0133.pdf

[31] Baker RC, Hogarty S, Poon W, Vadehra DV. "Survival of Salmonella typhimurium and Staphylococcus aureus in eggs cooked by different methods," Poultry Science, vol. 62, no. 7 (1983): 1211-1216. Copyright 2015 KEI Journals. All Rights Reserved url:

http://ps.oxfordjournals.org/content/62/7/12 11.short

[32] Bargellini A, Marchesi I, Rizzi L, Cauteruccio L, Masironi R, Simioli M, Borella P. "Selenium interactions with essential and toxic elements in egg yolk from commercial and fortified eggs," Journal of Trace Elements in Medicine and Biology, vol. 22, no. 3 (2008): 234-241. url: http://www.sciencedirect.com/science/article /pii/S0946672X08000345

[33] Barrow PA. "Experimental infection of chickens with Salmonella enteritidis," Avian Pathology, vol. 20, no. 2 (1991): 145-153. url:

http://www.tandfonline.com/doi/pdf/10.108 $\underline{0 / 03079459108418749}$

[34] Bellairs R, Boyde A. "Scanning Electron Microscopy of the shell membranes of the hen's egg," Cell and Tissue Research, vol. 96, no. 2 (1969): 237-249.

[35] Berger-Bachi B. "Resistance mechanisms of gram-positive bacteria," International Journal of Medical Microbiology, vol. 292, no. 1 (2002): 27-35. url:

http://www.sciencedirect.com/science/article /pii/S1438422104702076

[36] Berrang ME, Frank JF, Buhr JR, Bailey SJ, Cox NA. "Egg shell membrane structure and penetration by Salmonella typhimurium," Journal of Food Protection, vol. 62, no. 1 (1999): 73-76.

[37] Błądek T, Posyniak A, Gajda A, Gbylik M, Żmudzki J. "Multi-class procedure for analysis of antibacterial compounds in eggs by liquid chromatography-tandem mass 
spectrometry," Bull. Vet. Inst. Pulawy, vol. 56, no. 3 (2012): 321-327.

[38] Blankenship LC, Davis CE, Magner GJ. "Cooking methods for elimination of Salmonella typhimurium experimental surface contaminant from rare dry-roasted beef roasts," Journal of Food Science, vol. 45, no. 2 (1980): 270-273.

[39] Blumenthal D. "Salmonella enteritidis; from the chicken to the egg," FDA Consumer, vol. 24, no. 3 (1990): 7-11.

[40] Board R, Clay C, Lock J, Dolman J. "The egg: a compartmentalized, aseptically packaged food," in Microbiology of the Avian Egg, R.G. Board and R. Fuller, Eds, Chapman and Hall, London, 1994, pp. 4361.

[41] Borland ED. "Salmonella infection in poultry,". Veterinary Record, vol. 97, no. 21 (1975): 406-408.

[42] Burger J, Gochfeld M. "Cadmium and lead in common terns (Aves: Sterna hirundo): relationship between levels in parents and eggs," Environmental Monitoring and Assessment, vol. 16, no. 3 (1991): 253-258.

[43] Burjaq SZ, Shehabi AA. "Fresh leafy green vegetables associated with multidrug resistant E. coli," The International Arabic Journal of Antimicrobial Agents, vol. 3, no. 2 (2013): 1-7. url: http://www.imed.pub/ojs/index.php/IAJAA/ article/view/595

[44] Burley RW, Vadehra DV. The avian egg: Chemistry and Biology, John Wiley and Sons, NewYork, 1989.

[45] Cabello FC. "Heavy use of prophylactic antibiotics in aquaculture: A growing problem for human and animal Copyright 2015 KEI Journals. All Rights Reserved health and for the environment," Environmental Microbiology, vol. 8, no. 7 (2006): 1137-1144. url: http://onlinelibrary.wiley.com/doi/10.1111/j. 1462-2920.2006.01054.x/full

[46] Cason J, Bailey J, Cox N. "Location of Salmonella typhimurium during incubation and hatching of inoculated eggs," Poultry Science, vol. 72, no. 11 (1993): 2064-2068. url:

http://ps.oxfordjournals.org/content/72/11/2 064.short

[47] Catalano CR, Knabel SJ. "Destruction of Salmonella enteritidis by high $\mathrm{pH}$ and rapid chilling during simulated commercial egg processing," Journal of Food Protection, vol. 57, no. 7 (1994): 592-595.

[48] Chen J, Clarke RC, Griffiths MW. "Use of luminescent strains of Salmonella enteritidis to monitor contamination and survival in eggs," Journal of Food Protection, vol. 59, no. 9 (1996): 915-921.

[49] Chopra I, Roberts M. "Tetracycline antibiotics: mode of action, applications, molecular biology, and epidemiology of bacterial resistance," Microbiology and Molecular Biology Reviews, vol. 65, no. 2 (2001): 232-260.

[50] Darwish WS, Eldaly EA, El-Abbasy MT, Ikenaka Y, Nakayama S, Ishizuka M. "Antibiotic residues in food: the African scenario," Japanese Journal of Veterinary Research, vol. 61, suppl. (2013): S13-S22. url:

http://133.87.26.249/dspace/bitstream/2115/ 52350/1/JJVR61-S_REVIEW_02.pdf

[51] Davidson CM, Witty JK. "Fate of Salmonella in vacuum-packaged ground meat during storage and subsequent cooking," Canadian Institute of Food 
Science and Technology Journal, vol. 10, no. 3 (1997): 223-225.

[52] Demirulus H. "The heavy metal content in chicken eggs consumed in Van Lake territory," Ekoloji, vol. 22, no. 86 (2013): 19-25.

[53] De Reu K, Grijspeerdt K, Messens W, Heyndrickx M, Uyttendaelle M, Debevere J, Herman L. "Eggshell factors influencing eggshell penetration and whole egg contamination by different bacteria, including Salmonella enteritidis," International Journal of Food Microbiology, vol. 112 , no. 3 (2006): 253-260.

[54] Donoghue DJ. "Antibiotic residues in poultry tissues and eggs: human health concerns?" Poultry Science, vol. 82, no. 4 (2003): 618-621. url: http://ps.oxfordjournals.org/content/82/4/61 8.full.pdf

[55] Doyle ME, Mazzotta AS. "Review of studies on the thermal resistance of Salmonellae," Journal of Food Protection, vol. 63 , no. 6 (2000): 779-795.

[56] ECHM (Environmental Chemistry and Hazardous Materials), "Periodic table of elements,"

http://environmentalchemistry.com/yogi/peri odic. Accessed 15 March, 2015.

[57] Eckert KL, Eckert SA. "Embryo mortality and hatch success in in situ and translocated leatherback sea turtle (Dermochelys coriacea) eggs," Biological Conservation, vol. 53, no. 1 (1990): 37-46.

[58] Edwards JW, Edyvane KS, Boxall VA, Hamann M, Soole KL. 2001. "Metal levels in Seston and marine fish flesh near industrial and metropolitan centers in South Australia," Marine Pollution Bulletin, vol. 42, no. 5 (2001): 389-396. url: Copyright 2015 KEI Journals. All Rights Reserved http://www.researchgate.net/publication/119 $\underline{03883}$

[59] Eljarrat E, Monjonell A, Caixach J, Rivera J. "Toxic potency of polychlorinated dibenzo-p-dioxins, polychlorinated dibenzofurans, and polychlorinated biphenyls in food samples from Catalonia (Spain)," Journal of Agricultural and Food Chemistry, vol. 50, no. 5 (2002): 11611167.

url: http://pubs.acs.org/doi/abs/10.1021/jf011021 v

[60] Elshafie AE, Ba-Omar TA, Al-Bahry SN, Mahmoud IY, Alkindi AY, Alamri I. "Localization of fungal hyphae in the eggshells of the green sea turtle, Chelonia mydas from Ras Al-Hadd Reserve, Oman," Microscopy and Microanalysis, vol. 10, suppl. 2 (2004): 1536-1537.

[61] Elshafie AE, Al-Bahry SN, Al-Kindi AY, Ba-Omar T, Mahmoud IY. "Mycoflora and aflatoxins in soil, eggshells, and failed eggs of Chelonia mydas at Ras Al-Jinz, Oman," Chelonian Conservation and Biology, vol. 6, no. 2 (2007): 267-270.

[62] Fathi MM, Afifi YK, El-Safty SA. "Ultrastructural diversity of eggshell quality in some Egyptian local breeds of chicken," Egyptian Poultry Science, vol. 30, no. 3 (2010): 813-827. url: http://www.epsaegypt.com/wpcontent/uploads/2013/03/11-1216.pdf

[63] Focant JF, Eppe G, Pirard C, Massart $\mathrm{AC}$, André JE, De Pauw E. "Levels and congener distributions of PCDDs, PCDFs and non-ortho PCBs in Belgian foodstuffs: Assessment of dietary intake," Chemosphere, vol. 48, no. 2 (2002): 167$179 . \quad$ url: http://www.researchgate.net/publication/112618 $\underline{54}$

17 | P a g e 
[64] Gallani B, Verstraete F, Boix A, Von Holst C, Anklam E. "Levels of dioxins and dioxin-like PCBs in food and feed in Europe," Organohalogen Compounds, vol. 66 (2004): 1893-1900.

[65] Gantois I, Ducatelle R, Pasmans F, Haesebrouck F, Gast R, Humphrey TJ, Van Immerseel F. "Mechanisms of egg contamination by Salmonella enteritidis," FEMS Microbiology Reviews, vol. 33, no. 4 (2009): 718-738. url: http://femsre.oxfordjournals.org/content/33/ $\underline{4 / 718 . a b s t r a c t}$

[66] Gast RK. "Understanding Salmonella enteritidis in laying chickens: the contributions of experimental infections," International Journal of Food Microbiology, vol. 21, no. 1-2 (1994): 107-116.

[67] Gast RK, Holt PS. "Influence of the level and location of contamination on the multiplication of Salmonella enteritidis at different storage temperatures in experimentally inoculated eggs," Poultry Science, vol. 79, no. 4 (2000): 559-563. url: http://ps.oxfordjournals.org/content/79/4/55 9.full.pdf

[68] Graves RC, MacLaury DW. "The effects of temperature, vapor pressure and absolute humidity on bacterial contamination of shell eggs," Poultry Science, vol. 41, no. 4 (1962): 1219-1225. url:

http://ps.oxfordjournals.org/content/41/4/12 19.short

[69] Grijspeerdt K. "Modelling the penetration and growth of bacteria in eggs," Food Control, vol. 12, no. 1 (2001): 7-11. url:

http://www.sciencedirect.com/science/article /pii/S0956713500000153

Copyright 2015 KEI Journals. All Rights Reserved
[70] Hamm S, Grümping R, Schwietering J. "Levels of polychlorinated dibenzo(p)dioxins, dibenzofurans and dioxin-like PCBs in milk, milk products and eggs from West European countries," $25^{\text {th }}$ International Symposium on Halogenated Environmental Organic Pollutants, Toronto, Canada, 2005, pp. 1406-1408.

[71] Han FX, Banin A, Kingery WL, Triplet GB, Zhou LX, Zheng SJ, Ding WX. "New approach to studies of heavy metal redistribution in soil," Advances in Environmental Research, vol. 8, no. 1 (2003): $\quad 113-\quad 120 . \quad$ url: http://naulibrary.org/dglibrary/admin/book_ directory/Environmental management/4918. pdf

[72] He ZL, Yang XE, Stoffella PJ. "Trace elements in agroecosystems and impacts on the environment," Journal of Trace Elements in Medicine and Biology, vol. 19, no. 3 (2005): 125-140. url: http://www.sciencedirect.com/science/article /pii/S0946672X05000969

[73] Humphrey T. "Salmonella enteritidis PT4 infection in laying hens and consequences for egg contamination," in Quality of Poultry Products. 2, Eggs and Egg Products: Proceedings of the $4^{\text {th }}$ European Symposium on the Quality of Eggs and Egg Products, Doorwerth, Mary 12-17, 1991, A. Oosterwoud and A.W. de Vrie, Eds., Speldenholt Centre for Poultry Research and Information Services, Beekbergen, 1991, pp. 9-17.

[74] Humphrey TJ, Whitehead A. "Egg age and the growth of Salmonella enteritidis PT4 in egg contents," Epidemiology and Infection, vol. 111, no. 2 (1993): 209-219. url: 
http://www.ncbi.nlm.nih.gov/pmc/articles/P MC2271372/pdf/epidinfect00041-0030.pdf

[75] Humphrey TJ, Greenwood M, Gilbert RG, Rowe B, Chapman PA. "The survival of salmonellas in shell eggs cooked under simulated domestic conditions," Epidemiology and Infection, vol. 103, no. 1 (1989): 35-45. url: http://www.ncbi.nlm.nih.gov/pmc/articles/P MC2249479/pdf/epidinfect00016-0044.pdf

[76] Indar L, Baccus-Taylor G, Commissiong E, Prabhakar P, Reid H. "Salmonellosis in Trinidad: Evidence for transovarian transmission of Salmonella in farm eggs," West Indian Medical Journal, vol. 47, no. 2 (1998): 50-53.

[77] Javed T, Hameed A, Siddique M. "Egg shell penetration tendency of different Salmonella Serotypes by attached ring color method." Acta Microbiologica Polonica, vol. 43, no. 1 (1994): 67-72.

[78] Kenny C. "FDA inaction on antibiotics is making the world deadlier," Bloomberg Businessweek,

http://www.businessweek.com/articles/2013 -12-23/fda-inaction-on-antibiotics-ismaking-the-world-deadlier, 13 Dec. 2013.

[79] Khan S, Martin M, Bartsch H, Rahimtula, AD, "Perturbation of liver microsomal calcium homeostasis by ochratoxin A," Biochemical Pharmacology, vol. 38 , no. 1 (1989): 67-72.

[80] Kim CJ, Emery DA, Rinke H, Nagaraja KV, Halvorson DA. "Effect of time and temperature on growth of Salmonella enteritidis in experimentally inoculated eggs," Avian Diseases, vol. 33, no. 4 (1989): 735-742.

Copyright 2015 KEI Journals. All Rights Reserved
[81] Kojadinovic J, Potier M, Le Corre M, Cosson RP, Bustamante P. "Bioaccumulation of trace elements in pelagic fish from the Western Indian Ocean," Environmental Pollution, vol. 146, no. 2 (2007): 548-566. url: http://hal.univnantes.fr/file/index/docid/321778/filename/ Kojadinovic_et_al._ENPO_2007.pdf

[82] Kümmerer K. "Antibiotics in the aquatic environment. A review. Part I." Chemosphere, vol. 75, no. 4 (2009): 417434.

url: http://www.sciencedirect.com/science/article /pii/S0045653508015105

[83] Kümmerer K. "Antibiotics in the aquatic environment. A review. Part II." Chemosphere, vol. 75, no. 4 (2009): 435441.

url: http://www.sciencedirect.com/science/article /pii/S0045653508015099

[84] Limpus CJ, Reed P, Miller JD. "Islands and turtles: the influence of choice of nesting beach on sex ratio," in Proceedings of the Inaugural Great Barrier Reef Conference, Townsville, Queensland, 28 August-2 September 1983, J.T. Baker, R.M. Carter, P.W. Sammarco and K.P. Stark, Eds., James Cook University Press, Townsville, Queensland, Australia, 1983, pp. 397-402.

[85] Mahmoud IY, Al-Bahry SN, AlMusharafi SK. "Fresh water habitat pollution by treated sewage effluent in relation to multiple-antibiotic-resistant bacteria," APCBEES Procedia, vol. 5 (2013): 363 - $367 . \quad$ url: http://www.sciencedirect.com/science/article /pii/S2212670813000638

[86] Masshoff W, Stolpmann H. "Lichtund electronenmikroskopische $19 \mid \mathrm{P}$ a g e 
Untersuchungen an der Schalenhaut und Kalkschale des Huhnereies," Zeitschrift für Zellforschung, vol. 55, no. 6 (1961): 818832.

[87] Messens W, Grijspeerdt K, Herman L. "Eggshell penetration by Salmonella: a review," World's Poultry Science Journal, vol. 61, no. 1 (2005): 71-82.

[88] Miyamoto T, Horie T, Baba E, Sassai K, Fukata T, Arakawa A. "Salmonella penetration through eggshell associated with freshness of laid eggs and refrigeration," Journal of Food Protection, vol. 61, no. 3 (1998): 350-353

[89] Mo CL, Salas I, Caballero M. "Are fungi and bacteria responsible for olive ridley's egg loss?" in Proceedings of the 10th Annual Workshop on Sea Turtle Biology and Conservation, 20-24 February 1990, Hilton Head Island, South Carolina, T.H. Richardson, J.I. Richardson and M. Donnelly, Eds., NOAA Tech. Mem. NMFSSEFSC-278, 1990, pp. 249-252.

[90] Møller-Stray J, Eriksen HM, Bruheim T, Kapperud G, Lindstedt BA, Skeie A, Sunde M, Urdahl AM, Øygard B, Vold L. "Two outbreaks of diarrhoea in nurseries in Norway after farm visits, April to May 2009", Eurosurveillance, vol. 17, no. 47 (2012): 1-7. url: http://www.eurosurveillance.org/images/dyn amic/ee/v17n47/art20321.pdf

[91] Moss MO. "Mycotoxin review - 1. Aspergillus and Penicillium," Mycologist, vol. 16, no. 3 (2002): 116-119. url: http://www.davidmoore.org.uk/Assets/fungi 4schools/Reprints/Mycologist articles/Post16/Medical/v16pp116-119mycotoxins1.pdf

[92] Nascimento V, Cranstoun S, Solomon S. "Relationship between shell structure and Copyright 2015 KEI Journals. All Rights Reserved movement of Salmonella enteritidis across the eggshell wall," British Poultry Science, vol. 33, no. 1 (1992): 37-48.

[93] Padron M. "Salmonella typhimurium penetration through the eggshell of hatching eggs," Avian Diseases, vol. 34, no. 2 (1990): 463-465

[94] Peters A, Verhoeven KJF, Strijbosch H. "Hatching and emergence in the Turkish Mediterranean loggerhead turtle, Carretta carretta: natural causes for egg and hatching failure," Herpetologica, vol. 50, no. 3 (1994): 369-373. url: http://www.researchgate.net/publication/235 222177

[95] Phillott AD. "Pisonia grandis does not appear to harbour fungi known to invade sea turtle nests at Heron Island, Eastern Australia," Transactions of the Royal Society of South Australia, vol. 125, no. 1 (2001): 69-70.

[96] Phillott AD, Parmenter CJ. "The ultrastructure of sea turtle eggshell does not contribute to interspecies variation in fungal invasion of the egg," Canadian Journal of Zoology, vol. 84, no. 9 (2006): 1339-1344. url:

http://www.researchgate.net/publication/237 $\underline{973751}$

[97] Phillott AD, Parmenter CJ, Limpus CJ. "Mycoflora identified from failed green (Chelonia mydas) and loggerhead (Carretta carretta) sea turtle eggs at Heron Island, Australia," Chelonian Conservation and Biology, vol. 4, no. 1 (2001): 170-172.

[98] Pruden A, Arabi M, Storteboom HN. "Correlation between upstream human activities and riverine antibiotic resistance genes," Environmental Science \& Technology, vol. 46, no. 21 (2012): 11541-

$$
20 \mid \mathrm{P} \text { a g e }
$$


11549.

url:

http://pubs.acs.org/doi/abs/10.1021/es30265 $\underline{7 r}$

[99] Radu-Rusu CB, Pop IM, Albu A, Bologa M, Radu-Rusu RM. "Transferability of certain heavy metals from hens feed to table eggs laid within different rearing systems," Lucrări Ştiinţifice-Seria Zootehnie, vol. 59, no. 18 (2013): 218-222. url:

http://www.uaiasi.ro/revista_zoo/ro/docume nte/Pdf Vol 59/Cristina Radu Rusu.pdf

[100] Ritter L, Solomon KR, Forget J, Stemeroff M, O'Leary C. "Persistent organic pollutants," United Nations Environment Programme (UNEP), 2007, url: http://www.chem.unep.ch/pops/ Accessed March 2015.

[101] Ritz M, Freulet M, Orange N, Federighi M. "Effects of high hydrostatic pressure on membrane proteins of Salmonella typhimurium," International Journal of Food Microbiology, vol. 55, no. 1-3 (2000): 115-119. url: http://www.sciencedirect.com/science/article /pii/S0168160500001653

[102] Rupley JA. "The binding and cleavage by lysozyme of $\mathrm{N}$-acetylglucosamine oligosaccharides," Proceedings of the Royal Society B, vol. 167, no. 1009 (1967): 416428.

[103] Shahidul I, Tanaka M. "Impacts of pollution on coastal and marine ecosystems including coastal and marine fisheries and approach for management: a review and synthesis," Marine Pollution Bulletin, vol. 48, no. 7-8 (2004): 624-649. url: http://syarifahsari.lecture.ub.ac.id/files/2014/ 03/7.pdf

[104] Shalinsky EI. "The ultrastructure of the shell and shell membrane of chicken

Copyright 2015 KEI Journals. All Rights Reserved eggs," $6^{\text {th }}$ International Congress on Electron Microscopy (Japan), 1966, p. 579.

[105] Simkiss K. Calcium in reproductive physiology: a comparative study of vertebrates, Chapman and Hall, London, 1967.

[106] Solomon SE. Egg and eggshell quality, Iowa State University Press, Ames, Iowa USA, 1997.

[107] Solomon SE, Baird T. "The effect of fungal penetration on the eggshell of the green turtle," Proceedings of the Seventh European World Congress on Electron Microscopy, The Hague, the Netherlands, 24-29 August, 1980, P. Brederoo, Ed., vol. 2, Seventh European Congress on Electron Microscopy Foundation, Leiden, 1980, pp. 434-435.

[108] Solomon SE, Tippett R. "The intraclutch localisation of fungal hyphae in the egg shells of the leatherback turtle Dermochelys coriacea," Animal Technology, vol. 38, no. 2 (1987): 73-79.

[109] Sørensen PB, Vorkamp K, Thomsen M, Falk K, Møller S. Persistent organic pollutants (POPs) in the Greenland environment - Long-term temporal changes and effects on eggs of a bird of prey, National Environmental Research Institute. Ministry of the Environment, Denmark, $2004 . \quad$ url: http://www2.dmu.dk/1_viden/2_Publikation er/3_fagrapporter/rapporter/FR509.pdf

[110] Suzuki S, Hoa PTP. "Distribution of quinolines, sulfonamides, tetracyclines in the aquatic environment and antibiotic resistance in Indochina," Frontiers in Microbiology, vol. 3, no. 1 (2012): 1-8. url: http://www.ncbi.nlm.nih.gov/pmc/articles/P MC3283837I

$21 \mid \mathrm{Pag}$ e 
[111] Tan CK, Chen TW, Chan HL, Ng LS. "A scanning and transmission electron microscopic study of the membranes of chicken egg," Histology and Histopathology, vol. 7, no. 3 (1992): 339345.

url:

https://digitum.um.es/jspui/bitstream/10201/ 18333/1/A\%20scanning\%20and\%20transmi ssion\%20electron\%20microscopic\%20study \%20of\%20the\%20membranes\%20of\%20chi cken\%20egg.pdf

[112] Tyler C. "Avian eggshells: their structure and characteristics," in International Review of General and Experimental Zoology, W.J.L. Felts and R.J. Harrison, Eds., vol. 4, Academic Press, New York, 1969, pp. 81-130.

[113] Van Overmeire I, Pussemier L, Hanot V, De Temmerman L, Hoenig M, Goeyens I. "Chemical contamination of free-range eggs from Belgium," Food Additives and Contaminants, vol. 23, no. 11 (2006): 11091122.

[114] Wang H, Slavik MF. "Bacterial penetration into eggs washed with various chemicals and stored at different temperatures and times," Journal of Food Protection, vol. 61, no. 3 (1998): 276-279.

[115] WHO (World Health Organization), Antimicrobial resistance: global report on surveillance, World Health Organization. Geneva, Switzerland, $2014 . \quad$ url: http://www.who.int/drugresistance/documen ts/surveillancereport/en/

[116] Yang HM, Wang ZY, Lu J. "Study on the relationship between eggshell colors and egg quality as well as shell ultrastructure in Yangzhou chicken," African Journal of Biotechnology, vol. 8, no. 12 (2009): 28982902.

url: http://search.proquest.com/openview/2d49bf

Copyright 2015 KEI Journals. All Rights Reserved 0b32490430778327d5d75c6532/1?pqorigsite $=$ gscholar

[117] Yang SE, Yu RC, Chou CC. "Influence of holding temperature on the growth and survival of Salmonella spp. and Staphylococcus aureus and the production of staphylococcal enterotoxin in egg products," International Journal of Food Microbiology, vol. 63, no. 1-2 (2001): 99107.

url:

http://www.sciencedirect.com/science/article /pii/S0168160500004165

[118] Yildiz N, Yener G. "Dating of the sediment accumulation rate, radioactive and heavy metal pollution in the Van Lake." Ekoloji, vol. 19, no. 87 (2010): 80-87.

[119] Zhou J, Wang S, Nie F, Feng L, Zhu G, Jiang L. "Elaborate architecture of the hierarchical hen's eggshell." Nano Research, vol. 4, no. 2 (2011): 171-179. 